10. Кулицький С. Фармацевтична галузь і фармацевтичний ринок в Україні: стан і проблеми розвитку URL: http://www.nbuviap.gov.ua/ index.php?option=com_content $\&$ view=article \&id=4227:rinok-likarskikhzasobiv-v-ukrajini- $2 \&$ catid $=8 \&$ Itemid $=350$

11. Належна аптечна практика: Стандарти якості аптечних послуг (Спільна настанова МФФ/ВООЗ з НАП) URL: https://zakon.rada.gov.ua/ rada/show/897_009\#n2

12. Сталінська I. В., Абазін О. Зниження екологічного ризику при поводженні з побутовими медичними відходами. Вісник Національного університету водного господарства та природокористування. Технічні науки. Рівне, 2020. Випуск 1 (89), С. 74-83.

DOI https://doi.org/10.30525/978-9934-26-047-6-28

\title{
CURRENT PROBLEMS AND PROSPECTS OF MOLLUSCS FISHING IN THE NORTHWESTERN PART OF THE BLACK SEA
}

\author{
Shekk P. V. \\ Doctor of Agricultural Sciences, Professor, \\ Head of the Aquatic Bioresources and Aquaculture Department \\ Odesa State Environment University \\ Burhaz M. I. \\ Candidate of Biological Sciences, \\ Associate Professor at the Aquatic Bioresources and Aquaculture \\ Department \\ Odesa State Environment University
}

Matviienko T. I.

Senior Lecturer at the Aquatic Bioresources and Aquaculture Department Odesa State Environment University

Odesa, Ukraine

In recent decades, the ecosystem of the northwestern Black Sea has undergone significant changes under the influence of anthropogenic factors, which are accompanied by a decrease in the bioresources at all trophic levels and in the biodiversity in general, which in turn reduces catching the main fishery objects. There is a transformation in the extraction of aquatic 
bioresources in the north-western part of the Black Sea and a replacement of fish species by mollusks.

Due to the loss of the fishing areas around the Crimean Peninsula, due to the temporary occupation, fishing in the north-western part of the Black Sea has been intensified.

During the last five years, there was a downward trend in catching the small fish species (sprat, anchovy, horse mackerel, red mullet) and a rapid increase in rapan catches. The rapan catches increased from 200 tons in 2014 to more than 11,000 tons in 2019. Thus, in 2019, rapan catches accounted for about $80 \%$ of total catching the aquatic bioresources in the northwestern Black Sea.

Against an increase in the rapan catches, a decrease in the mussel catches is observed. Thus, the highest rate of mussel catches was recorded in 2016 (502.0 tons), in 2019 the catch rate decreased more than 2 times compared to 2016 (236.1 tons).

The rapan biomass in the waters of Ukraine in the north-western part of the Black Sea was estimated by the methods of mathematical modeling at the level of 28.9 thousand tons. The stock assessment for the whole sea was obtained jointly with the expert group of the General Fisheries Commission for the Mediterranean (GFCM) and the European Union and it was 116,000 tonnes. The biomass continues to remain high. Apparently, this is due to the fact that the fishery uses less than $20 \%$ of the water area inhabited by rapans.

It is clear that the abnormal distribution of rapans in the Black Sea and the serious deterioration of the marine environment caused by it require the effective action. In this situation, it is advisable to encourage the capture of rapans by all possible forces and means that do not harm the ecosystem. To do this, in addition to traditional diving collecting and extracting with the help of Khyzhnyak's dredge, it is necessary to develop new effective and environmentally friendly fishing gear, taking into account the experience of other Black Sea countries.

With regard to mussel harvesting, one of the effective ways to improve the mussel population is to use its available stocks for the conchioculture.

In the north-western part of the Black Sea, the area of lagoon-type waters suitable for mariculture is about 200 thousand hectares. In addition, modern mariculture technologies allow to use the high seas with depths of 10-30 m, which area in the economic zone is quite large.

Foreign experience shows that mariculture develops only with a state support. Mariculture was most developed in China after this industry became a priority in the country. The annual increase in seafood production in China 
has reached fantastic levels: more than 1 million tons. In European countries, in particular in France, mariculture enjoys a multilateral support from the state (soft loans, non-repayable loans to novice farmers, free consultations, training, benefits in the formation of cooperatives, etc.).

Conchioculture is a promising area of mariculture for our country. So, mussels feed natural food, filtering it from sea water, so the concern for food is eliminated. Planting material (young) for further cultivation comes to the plantation with the current itself. Adult mussels do not move, which simplifies the technical means of cultivation and reduces capital costs. And the mussel itself contains microelements, vitamins, all necessary amino acids and substances to strengthen the immune system (immunomodulators). In addition, nowadays the mollusc farming biotechnology in other countries is at a fairly high level, and their experience can be used for the waters of the north-western part of the Black Sea.

Based on the above, we can conclude that the effective using of Black Sea mollusks requires support from the state. The main organizational and legal components of the domestic public policy in the field of fisheries are:

(a) national legislation governing, regulating and supporting the fisheries industry and its development. The main items of the state fishery policy are formed in the relevant laws;

b) normalizing the allowable catch, aimed at a guaranteed satisfaction of a stock state of the major industrial objects;

c) fishing quotas, which are associated with the distribution and issuance of the quotas for catching the aquatic bioresources and perform the resourcesaving and budget-filling functions;

d) creating the favorable conditions for ensuring the fisheries development and its competitiveness in the domestic and foreign markets;

e) harmonization of the national standards, the food quality and safety assurance systems and international requirements, which are a prerequisite for integrating into the world economic community. In particular, the HACCP management system (Hazard Analysis and Critical Control Point) must be mandatory introduced at the fisheries enterprises.

The perspective areas of fishing are rapan extracting and mussel farming, taking into account a current state of the Black Sea ecosystem. Despite the socio-economic difficulties that have gripped many countries around the world, there is still much room for developing and managing the marine industry in the north-western part of the Black Sea, which development can be accelerated by the effective fisheries reforms and a targeted state support. 


\section{References:}

1. Популяционные характеристики поселений мидии MYTILUS GALLOPROVINCIALIS LAM. на разных субстратах Одесского залива. Стадниченко С.В., 2010, УДК 594.124(262.5) - С. 82-77 с.

2. Rapa whelk controls demersal community structure off Zmiinyi Island, Black Sea.S Snigirov, V Medinets, V Chichkin, S Sylantyev quatic Invasions 8, 2013.

3. Оценка влияния хищного брюхоногого моллюска Rapana venosa (Valenciennes, 1864) на фильтрационный потенциал мидий Mytilus galloprovincialis Lam. / И. А. Говорин, А. П. Куракин // Екол. безпека прибереж. та шельф. зон та комплекс. використ. ресурсів шельфу: зб. наук. пр. - 2011. - 25, Т. 1. - С. 435-442.

4. Сравнительная морфологическая характеристика Rapana venosa (Gastropoda: Muricidae, Rapaninae) из разных акваторий северной части Черного моря.//Вісник ОНУ. Ковтун О.А., Тоцкий В.Н.Сер.: Біологія. 2014. Т. 19, вип. 1(34)

5. Основные результаты комплексных исследований в АзовоЧерноморском бассейне и мировом океане//ЮгНИРО. Том 51. 2013.

6. Звіт про науково-дослідну роботу «Вивчення промисловго значення концентрації молюска рапани у північно-західній частині Чорного моря та уточнення технічних характеристик найбільш ефективних і екологічно безпечних знарядь його добування»//ДП «ОдЦ ПівденНІРО». 2018.

7. Звіт про науково-дослідну роботу «Оцінка запасів основних промислових об'єктів північно-західного Причорномор'я»// ДП «ОдЦ ПівденНІРО». 2019. 